\title{
A PRELIMINARY REPORT ON MITES (ACARI) ASSOCIATED WITH THE SMALL SPRUCE BARK BEETLE IPS AMITINUS (COLEOPTERA: CURCULIONIDAE: SCOLYTINAE) IN WESTERN SIBERIA
}

\author{
Alexander A. Khaustov ${ }^{1 *}$ and Ivan A. Kerchevi,2
}

\author{
${ }^{1} \mathrm{X}-\mathrm{BIO}$ Institute, Tyumen State University, Tyumen, Russia \\ ${ }^{2}$ Institute of Monitoring of Climatic and Ecological Systems, Tomsk, Russia \\ *corresponding author; e-mail: alex1973khaustov@gmail.com
}

\begin{abstract}
The small spruce bark beetle Ips amitinus has recently been found in two West Siberian regions: Tomsk and Kemerovo. Here, we collected and identified the mites associated with $I$. amitinus that naturally colonized branches and twigs of Siberian pine, Pinus sibirica, in Western Siberia, Russia. Five mites species were revealed: Dendrolaelaps quadrisetus (Digamasellidae), Proctolaelaps hystricoides (Melicharidae), Iponemus leionotum and I. asiaticus (Tarsonemidae), as well as Ereynetes (Huntereynetes) sp. (Ereynetidae). Interestingly, phoresy of two species of Iponemus was observed on one host beetle. Three of the five species are known predators and parasitoids of eggs or larvae of bark beetles and could be targeted for biological control of I. amitinus in Russia.
\end{abstract}

KEY WORDS: Acarina, phoresy, SEM photographs, small spruce beetle, parasitoids, predators.

DOI: 10.21684/0132-8077-2020-28-1-39-46

\section{INTRODUCTION}

Bark beetles (Coleoptera: Curculionidae, Scolytinae) are one of the most important components of forest communities (Harvey et al. 2013; Raffa et al. 2015). Their role in the ecosystem consists of eliminating weakened trees, thereby accelerating the carbon cycle (Ayres et al. 2000; Petrov and Dostovalov 2015) and regulating forest structure and processes (Goheen and Hansen 1993). Bark beetles excavate galleries in the inner bark and phloem of the host plants, creating environmental niches for a rather diverse group of organisms: fungi, bacteria, invertebrates and protozoa (Biederman et al. 2019).

Mites are known to associate with various bark beetles (Coleoptera: Curculionidae, Scolytinae) (Lindquist 1970; Hofstetter et al. 2013). They include predators, preying on bark beetle eggs and larvae, nematodes and other mites that inhabit bark beetle galleries. This group of mites also includes myco- and saprophagous mites, as well as parasitoids of bark beetle eggs and other beetle instars (Hofstetter et al. 2015). Most mites that inhabit bark beetle galleries use adult beetles for phoresy (Lindquist 1970). The association of mite communities to particular bark beetle species has only been studied in the context of a few cases associated with economically important pests. They include: Dendroctonus frontalis in North and Central America (Moser and Roton 1971; Kinn and Swanston 1976; Stephen and Kinn 1980; Hofstetter 2011; Klepzig and Hofstetter 2011); Ips typographus, I. sexdentatus, Pytyocteines spp, Scolytus multistriatus, S. pygmaeus in Europe (Lieutier 1978; Moser and Bogenschütz 1984; Moser et al. 1989; Pernek et al. 2008, 2012; Takov et al. 2009; Gwiazdowicz et al. 2011, 2012, 2015; Vrabec et al. 2012; Moraza et al. 2013; Penttinen et al. 2013; Čejka and Holuša 2014); and Ips typographus japonicus in Japan (Moser et al. 1997). In Western Siberia, only mite communities associated with Pityogenes chalcographus and Ips typographus have been studied (Khaustov et al. 2016, 2018).

Small spruce bark beetle Ips amitinus (Eichhoff, 1872), which originated from a glacial conifer refugia in the Central European Highlands, first appeared in Northern Europe at the beginning of 1900s (Økland et al. 2019). This beetle's range expansion was first documented in Estonia in the 1930s. By 1951, the species was recorded in southwestern Finland (Voolma et al. 2004; Økland et al. 2019). In the Leningrad Region of Russia, this bark beetle was first recorded in 1976 (Mandelshtam 1999). Recent expansion of the I. amitinus range has been rapid and has likely reached the northernmost conifer stands of the Pasvik Nature Reserve, located in the Murmansk Region of European Russia (Shcherbakov et al. 2013). Such an unexpected invasion of this species into an area so far from its native habitat has highlighted that the economic importance of I. amitinus as a forest pest has been underestimated. In 2019, this beetle was recorded in two West Siberian regions-Tomsk and Kemerovo-where it was responsible for substantial economic losses associated with the killing of approximately one thousand hectares of Siberian pine stands (Kerchev et al. 2019). 
Very little is known about mites associated with Ips amitinus. Lindquist (1969) reported phoresy of Iponemus gaebleri gaebleri (Schaarschmidt, 1959) (Tarsonemidae) in Poland. Khaustov (1999) recorded Aethyophenax ipidarius (Redikortzev, 1947) on I. amitinus in the Leningrad Region of Russia. Kielczewski and Wisniewski $(1978,1983)$ found Siculobata (Paraleius) leontonycha (Berlese, 1910) and Trichouropoda polytricha (Vitzthum, 1923) (Trematuridae) in the galleries of I. amitinus in Poland.

Our objective was to document the mites associated with Ips amitinus from Siberian pine in the Tomsk Region of Western Siberia, Russia.

\section{MATERIALS AND METHODS}

Branches and twigs of the Siberian pine, Pinus sibirica, containing overwintering bark beetles Ips amitinus (Eichhoff, 1871), were collected from several pure Siberian pine stand localities in the vicinity of the settlements of Bazoy $\left(55^{\circ} 44^{\prime} \mathrm{N}\right.$, $\left.83^{\circ} 22^{\prime} \mathrm{E}\right)$ and Luchanovo $\left(56^{\circ} 21^{\prime} \mathrm{N}, 85^{\circ} 03^{\prime} \mathrm{E}\right)$, Tomsk Region, Russia, between January 23 and February 6, 2020. The samples were placed into plastic bags and kept at room temperature in the laboratory. About 200 beetles that were leaving the branches and twigs were collected with an aspirator, after which they were placed into vials containing $96 \%$ ethanol. Thereafter, the alcohol sediments from the vials were inspected for phoretic mites. Bark beetle surfaces and their subelytral cavities were also inspected. Galleries of Ips amitinus were examined in some samples. For these purposes, the bark containing beetle galleries was removed and examined with a microscope (Discovery V8, Carl Zeiss stereomicroscope). The mites were imaged with a scanning electron microscope (SEM; TESCAN Mira3 LMU SEM microscope). For SEM microscopy, live beetles with phoretic mites were scanned without coating. Additional photomicrographs were taken with a digital camera (Hitachi KP-HD20A, Japan). The mites were mounted in Hoyer's medium for lightmicroscopy. The morphology of mites was studied using the Carl Zeiss Axio Imager A2 microscope with phase contrast and DIC illumination. The studied material was then deposited in the mite collection of the Tyumen State University Museum of Zoology, Tyumen, Russia.

\section{RESULTS}

\section{Order Mesostigmata}

Family Digamasellidae

\section{Dendrolaelaps (Ipidodendrolaelaps) quadrisetus (Berlese, 1920)}

(Fig. 1)

This species is known from the Palaearctic (widely distributed in Europe; known from Algeria, Asian Russia and Japan), Nearctic (USA, Canada, Mexico) and the Neotropics (Guatemala) (Shcherbak 1980; Hirschmann and Wiśniewski 1982; ChairesGrijalva et al. 2013; Knee et al. 2013; Khaustov et al. 2018). These mites were found to be associated with many species of pine bark beetles, inhabiting various coniferous trees (Khaustov et al. 2018). In Russia, this species is known from Arkhangelsk Region, Primorye Territory (Shcherbak 1980) and Western Siberia (Khaustov et al. 2018). This species is a predator of eggs and immature stages of bark beetles (Kinn 1967). Khaustov et al. (2018) observed deutonymphs of $D$. quadrisetus feeding on Ips typographus eggs. Most likely, this feeding is necessary for the deutonymphs' normal development and molting into the adult stage. Deutonymphs of D. quadrisetus are usually phoretic on the elytral declivity (Figs. 1A) or under the elytra of bark beetles (Fig. 3). Deutonymphs of D. quadrisetus are similar to those of D. quadrisetosimilis (Fig. 2D-F), differing in the lack of delicate striation on dorsal shields (Figs. 1C, D).

Dendrolaelaps quadrisetus was the most abundant mite species in our samples. This article presents the first record of phoresy of $D$. quadrisetus on I. amitinus.

Material examined. More than 100 deutonymphs phoretic mostly under elytra of I. amitinus, and some found in galleries under the bark of Pinus sibirica.

\section{Family Melicharidae}

\section{Proctolaelaps hystricoides Lindquist and Hunter, 1965}

This species inhabits galleries of subcortical insects and it is phoretic on various bark beetles in Canada and the USA (Lindquist and Hunter 1965). It has also been recorded from Iran (Kazemi and Rajaei 2013) and Croatia (Pernek et al. 2008). In Asian Russia, this species was found to be associated with Pityogenes chalcographus, Polygraphus proximus, Hylurgops glabratus, Ips subelongatus and I. typographus (Trach and Khaustov 2017).

Material examined. Three Proctolaelaps hystricoides females were collected in the galleries of I. amitinus under the bark of Pinus sibirica. 


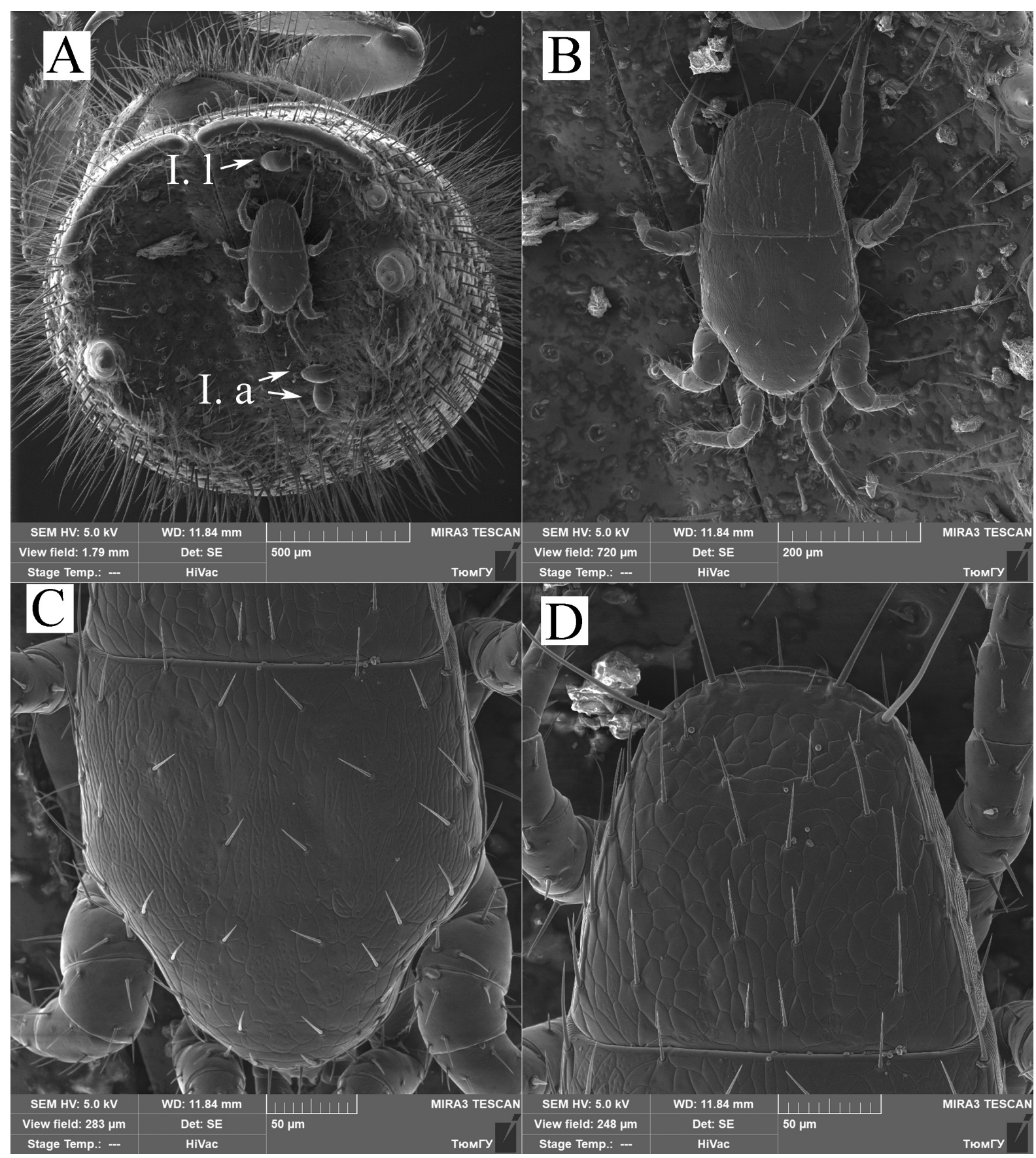

Fig 1. SEM photographs of mites phoretic on Ips amitinus. A - general view of elytral declivity with three species of phoretic mites: Iponemus asiaticus (I. a), Iponemus leionotum (I. 1) and Dendrolaelaps quadrisetus (the large mite in the center); B - deutonymph of Dendrolaelaps quadrisetus (B-D), general view; C - anterior half of idiosoma in dorsal view; D—posterior half of idiosoma in dorsal view.

Order Trombidiformes

Suborder Prostigmata

Family Tarsonemidae

\section{Iponemus leionotum Lindquist, 1969}

(Figs. 1A, 2A, B)

This species is known from China, Hungary, Italy and Russia (Western Caucasus) (Lindquist
1969). Phoretic females usually attach to the elytral declivity of bark beetles (Fig. 1A). Although its main host is Ips sexdentatus, it also known as an associate of I. acuminatus. In Western Siberia, it was collected from I. sexdentatus and I. duplicatus (Khaustov et al. 2017). This species is characterized by setae $c_{1}$ being longer than $c_{2}$, very small dimples on the dorsal shields and the presence of longitudinal striation only on the laterad setae $d$ (Fig. 2B). 


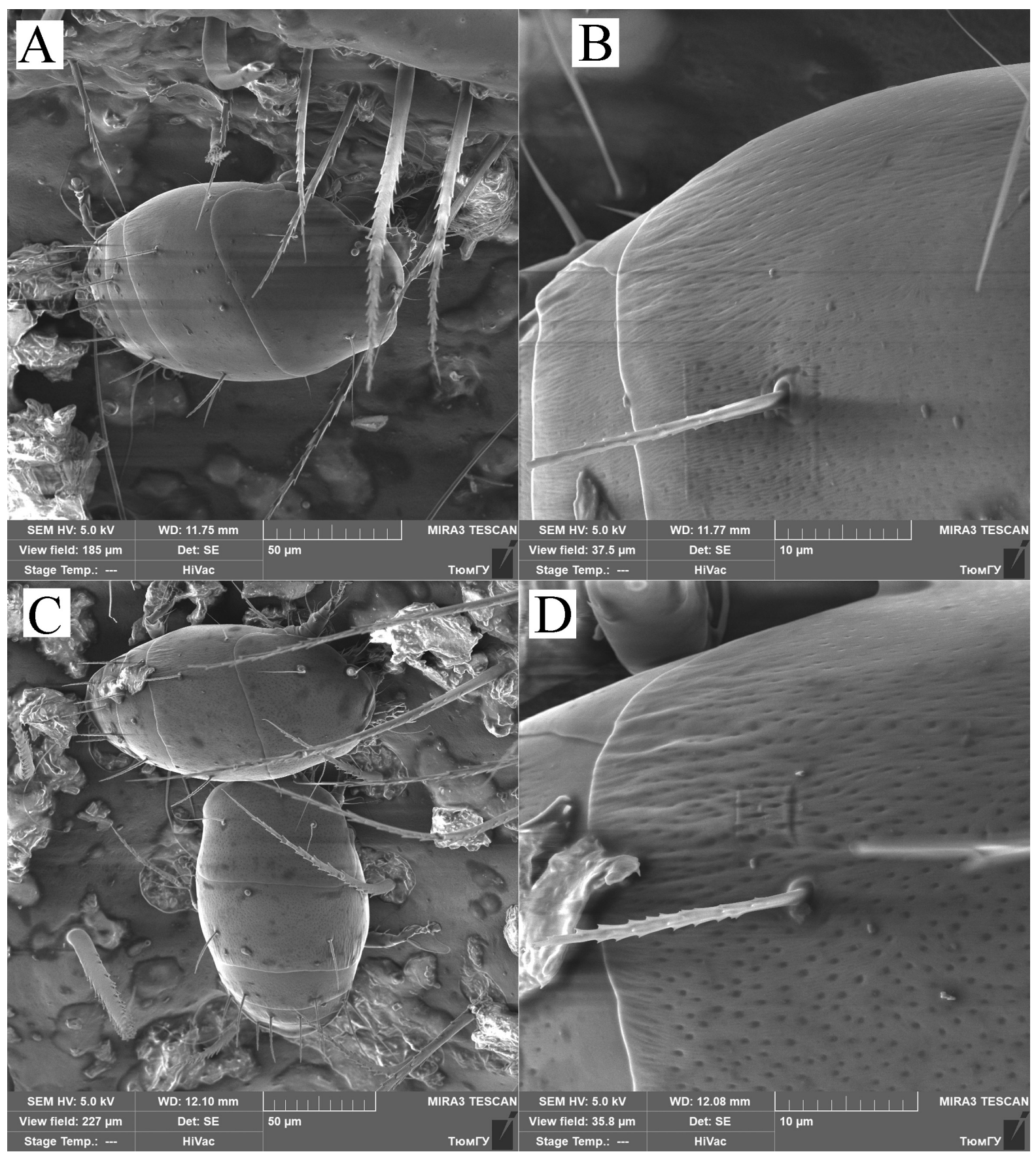

Fig. 2. SEM photographs of Iponemus phoretic females: A-I. leionotum, general view; B-left half of tergite D of I. leionotum; C-I. asiaticus, general view; D-left half of tergite D of I. asiaticus.

Ips amitinus is a newly discovered phoretic host of I. leionotum. Few I. leionotum were observed with a maximum quantity of one female per beetle.

Material examined. Ten I. leionotum females on elytral declivity of I. amitinus. None were observed in galleries of I. amitinus under the bark of Pinus sibirica.

\section{Iponemus asiaticus Lindquist, 1969}

(Figs. 1A, 2C, D)

This species is known from Asian Russia, China, Poland and Japan (Lindquist 1969). Its main host is Ips subelongatus, but it is also known as an associate of Ips cembrae, I. hauseri and I. duplicatus (Lindquist 1969). Similar to I. leionotum, only females are phoretic and typically found on the elytral declivity of bark beetles (Fig. 1A). This species is characterized by subequal setae $c_{1}$ and 


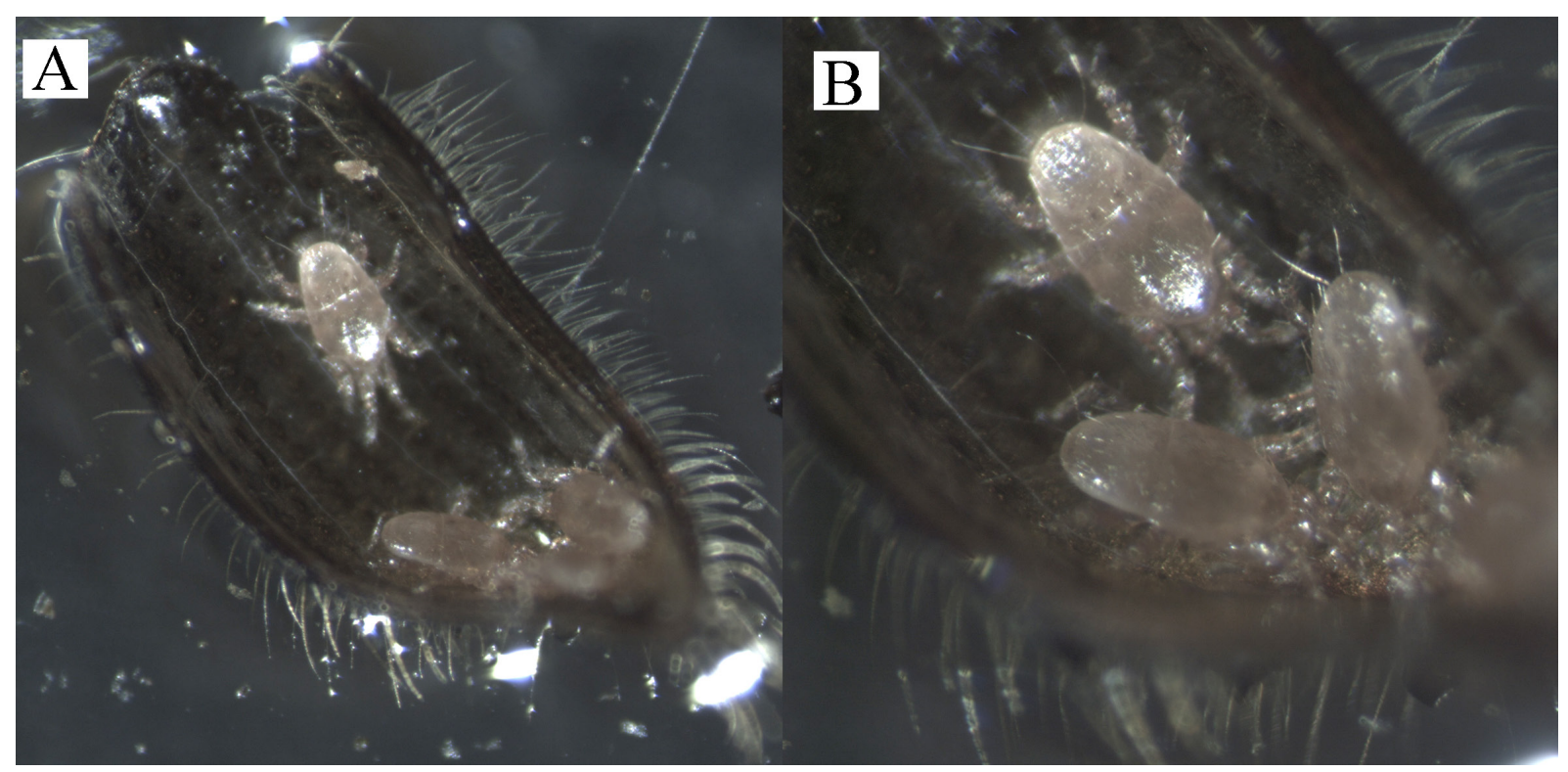

Fig. 3. Photomicrograph of detached elytron of Ips amitinus with phoretic deutonymphs of Dendrolaelaps quadrisetus: A-general view; B-distal part of elytron.

$c_{2}$, large dimples on the dorsal shields and the presence of longitudinal striation on only the laterad setae $d$ (Fig. 2D).

Ips amitinus is a new phoretic host of I. asiaticus. In our samples, it was more abundant than I. leionotum: maximum of three females per beetle were found.

Material examined. More than 50 I. leionotum females on elytral declivity of about 100 I. amitinus beetles.

\section{Family Ereynetidae}

\section{Ereynetes (Huntereynetes) sp.}

This species has been reported as Ereynetes scutulis Hunter, 1964, E. near scutulis and E. propescutulis Hunter and Rosario, 1989 from several localities in Europe in associations with various bark beetles (Moser et al. 1989; Pernek et al. 2008; Penttinen et al. 2013). In western Siberia, it was found in association with Ips typographus (Khaustov et al. 2018).

This species has no specific attachment site on the beetle host; it actively moves around the beetle's body during phoresy. In our samples, it was the rarest species.

Material examined. Two Ereynetes females in alcohol sediments containing I. amitinus.

\section{DISCUSSION}

The mite community associated with Ips amitinus collected in the bark beetle invasion area has no specificity to this particular beetle species. The mite species are known to widely distribute and associate with many bark beetle species. However, the presence of two different species of Iponemus on a single host beetle is a very rare phenomenon. Previously, it was reported only for I. gaebleri and I. leionotum, phoretic on Ips duplicatus in Western Siberia (Khaustov et al. 2017). Undoubtedly, I. leionotum and I. asiaticus switched from their main hosts (Ips sexdentatus and I. subelongatus, respectively) to I. amitinus. Because Ips amitinus, I. sexdentatus and I. subelongatus attack Siberian pines (Pinus sibirica) in western Siberia (Stark 1952; Kerchev et al. 2019), their galleries may intersect. Therefore, mites can freely move through the galleries from one bark beetle species to another.

Through the use of electron microscopy, we were able to establish that the mites of two species of the genus Iponemus were located on different parts of a bark beetle declivity: Iponemus leionotum attached to the lower part, and I. asiaticusto the upper (Fig. 1A). Three of the five species of mites found on Ips amitinus could have a direct effect on bark beetle survival and population growth. In particular, Iponemus leionotum and I. asiaticus are parasitoids of bark beetle eggs, while Dendrolaelaps quadrisetus is a specialized predator of bark beetle eggs and juvenile instars. These findings create the basis for using the above mites to biologically control the invasive bark beetle Ips amitinus. 


\section{ACKNOWLEDGEMENTS}

We thank A. A. Gubin (Tyumen State University) for preparing the SEM photographs. We also thank Dr. Omid Joharchi (Tyumen State University) for helping with the identification of mesostigmatic mites. The study was supported by the Russian Foundation for Basic Research (RFBR), research project No. 20-04-00587.

\section{REFERENCES}

Ayres, M.P., Wilkens, R.T., Ruel, J.J. and Vallery, E. 2000. Fungal relationships and the nitrogen budget of phloem-feeding bark beetles (Coleoptera: Scolytidae). Ecology, 81: 2198-2210.

Biedermann, P.H., Grégoire, J., Gruppe, A., Hagge, J., Hammerbacher, A., Hofstetter, R., Kandasamy, D., Kolařík, M., Kostovčík, M., Krokene, P., Mueller, J., Sallé, A., Six, D.L., Turrini, T., Vanderpool, D., Wingfield, M.J. and Bässler, C. 2019. Bark Beetle Population Dynamics in the Anthropocene: Challenges and Solutions. Trends in Ecology and Evolution, 34(10): 914-924. DOI: 10.1016/ j.tree.2019.06.002

Čejka, M. and Holuša, J. 2014. Phoretic mites in uniand bivoltine populations of Ips typographus: a 1-year case study. Turkish Journal of Zoology, 38: 569-574.

Chaires-Grijalva, M.P., Estrada-Venegas, E.J., Equihua-Martínez, A., Moser, J.C., Sánchez-Martínez, G., Vázquez-Rojas, I.M., Otero-Colina, G. and Romero-Nápoles, J. 2013. Mesostigmados (Acari: Mesostigmata) asociados con Dendroctonus rhizophagus de Chihuahua, México. Revista Mexicana de Biodiversidad, 84: 1235-1242.

Goheen, D.J. and Hansen, E.M. 1993. Effects of pathogens and bark beetles on forests. Beetle-Pathogen Interactions in Conifer Forests. TD Schowalter and GM Filip, eds. Academic Press. San Diego, 175-196.

Gwiazdowicz, D. J., Bloszyk, J. and Gdula, A.K. 2015. Alpha diversity of mesostigmatid mites associated with the bark beetle Ips typographus (L.) in Poland. Insect Conservation and Diversity, 8: 448-455.

Gwiazdowicz, D. J., Kamczyc, J. and Błoszyk, J. 2011. The diversity of phoretic Mesostigmata on Ips typographus (Coleoptera: Scolytinae) caught in the Karkonosze forest. European Journal of Entomology, 108: 489-491.

Gwiazdowicz, D.J., Kamczyc, J., Teodorowicz, E. and Błoszyk, J. 2012. Mite communities (Acari, Mesostigmata) associated with Ips typographus (Coleoptera, Scolytidae) in managed and natural Norway spruce stands in Central Europe. Central European Journal of Biology, 7: 910-916.
Harvey B.J., Donato D.C., Romme W.H. and Turner M.G. 2013. Influence of recent bark beetle outbreak on fire severity and postfire tree regeneration in montane Douglas-fir forests. Ecology, 94: 2475-2486.

Hirschmann, W. and J. Wioeniewski. 1982. Weltweite revision der Gattungen Dendrolaelaps Halbert 1915 und Longoseius Chant 1961 (Parasitiformes). Band II. Acarologie, 29: 1-48, 1-94 pl.

Hofstetter, R.W. 2011. Mutualists and Phoronts of the Southern Pine Beetle. In: K.D. Klepzig and R. Coulson (Eds.). Southern Pine Beetle II. United States Department of Agriculture Forest Service, Southern Research Station General Technical Report SRS140, pp. 161-181.

Hofstetter, R. W., Moser, J.C. and Blomquist, S. 2013. Mites associated with bark beetles and their hypophoretic Ophiostomatoid fungi. In: K.A. Seifert, Z.W. de Beer and M. J. Wingfield (Eds.). The Ophiostomatoid Fungi: Expanding Frontiers. Chapter 12. $1^{\text {st }}$ edition. CBS Biodiversity Series 12 . KNAW Fungal Biodiversity Centre, Utrecht, The Netherlands, pp. 165-176.

Hofstetter, R.W., Dinkins-Bookwalter, J., Davis, T.S. and Klepzig, K.D. 2015. Symbiotic associations of bark beetles. In: F.E. Vega and R. W. Hofstetter (Eds.). Bark Beetles, Biology and Ecology of Native and Invasive species. Chapter 6. $1^{\text {st }}$ edition. Academic Press, Elsevier, pp. 209-245.

Kazemi, S. and Rajaei, A. 2013. An annotated checklist of Iranian Mesostigmata (Acari), excluding the family Phytoseiidae. Persian Journal of Acarology, 2: 63-158.

Kerchev, I. A., Mandelshtam, M. Yu., Krivets, S.A. and Ilinsky, Y.Y. 2019. Small spruce bark beetle Ips amitinus (Eichhoff, 1872) (Coleoptera, Curculionidae: Scolytinae): a new alien species in West Siberia. Entomological Review, 99(5): 639-644.

Khaustov, A.A. 1999. The redescription of 〈Pediculoides〉 ipidarius Redikortsev, 1947, with description of the new species from the genus Paracarophenax (Acari: Heterostigmata: Acarophenacidae). Acarina, 7: 57-59.

Khaustov, A.A., Tolstikov, A.V. and Ermilov, S.G. 2017. Parasitoid mites (Acari: Heterostigmata) of bark beetles (Coleoptera: Curculionidae: Scolytinae) of Western Siberia. In: Abstract book of the third International Persian Congress of Acarology, 23-25 August 2017, pp. 23-24.

Khaustov, A. A., Trach, V.A. and Bobylev, A.N. 2016. Mites (Acari) phoretic on six-toothed spruce bark beetle, Pityogenes chalcographus Linnaeus (Coleoptera: Curculionidae: Scolytinae), in Western Siberia, Russia. Acarina, 24(2): 137-151. DOI: 10.21684/0132-8077-2016-24-2-137-151 
Khaustov, A.A., Klimov, P.B., Trach, V.A., Bobylev, A.N., Salavatulin, V.M., Khaustov, V.A. and Tolstikov, A. V. 2018. Review of mites (Acari) associated with the European spruce bark beetle, Ips typographus (Coleoptera: Curculionidae: Scolytinae) in Asian Russia. Acarina, 26 (1): 3-79. DOI: 10.21684/0132-8077-2018-26-1-3-79

Kiełczewski, B. and Wiśniewski, J. 1978. Bark beetle acarofauna in different types of forest habitat. Part IV. Bulletin de la Société des amis des sciences et des lettres de Poznań, Serie D, 18: 119-133.

Kielczewski, B. and Wisniewski, J. 1983. Bark beetle acarofauna in different types of forest habitat. Part I and II. Introduction and Mesostigmata. Folia Forestalia Polonica, Seria A, 25: 129-162.

Kinn, D.N. and Swanston, D.N. 1976. Key to Mites Commonly Associated with the Southern Pine Beetle. Department of Agriculture, Forest Service, Southern Forest Experiment Station, New Orleans, LA. 11 pp.

Kinn, D.N. 1967. Notes on the life cycle and habits of Digamasellus quadrisetus (Mesostigmata: Digamasellidae). Annals of the Entomological Society of America, 60: 862-865.

Klepzig, K. D. and Hofstetter R. W. 2011. From Attack to Emergence: Interactions between southern pine beetle, mites, microbes and trees. In: K.D. Klepzig and R. Coulson (Eds.). Southern Pine Beetle II. United States Department of Agriculture Forest Service, Southern Research Station General Technical Report SRS-140, pp. 141-152.

Knee, W., Forbes, M.R. and Beaulieu, F. 2013. Diversity and host use of mites (Acari: Mesostigmata, Oribatida) phoretic on bark beetles (Coleoptera: Scolytinae): global generalists, local specialists? Annals of the Entomological Society of America, 106: 339-350.

Lieutier, F. 1978. Les acariens associes a Ips typographus et Ips sexdentatus (Coleoptera: Scolytidae) en region parisienne et les variations de leurs populations au cours du cycle annuel. Bulletin d'Ecologie, 9: 307-321.

Lindquist, E.E. 1969. Review of Holarctic tarsonemid mites (Acarina: Prostigmata) parasitizing eggs of ipine bark beetles. Memoirs of the Entomological Society of Canada, 101: 5-111.

Lindquist, E.E. 1970. Relationships between mites and insects in forest habitats. Canadian Entomologist, 102: 978-984.

Lindquist, E.E. and Hunter, P.E. 1965. Some mites of the genus Proctolaelaps Berlese (Acarina: Blattisociidae) associated with forest insect pests. $\mathrm{Ca}$ nadian Entomologist, 97: 16-32.

Mandelshtam, M. 1999. Notes on the current status of Ips amitinus Eichh. (Coleoptera, Scolytidae) in NorthWest Russia. Entomologica Fennica, 10(1): 29-34.
Moraza, M.L., Fernández, M. and Jurc, M. 2013. Phoretic mites of the six-spined engraver beetle, Ips sexdentatus (Böerner, 1776) (Coleoptera, Scolytinae), on Pinus halepensis in Slovenia. International Journal of Acarology, 39: 597-599.

Moser, J.C. and Bogenschütz, H. 1984. A key to the mites associated with flying Ips typographus in South Germany. Zeitschrift für Entomologie, 97: 437-450.

Moser, J.C., Eidmann, H.H. and Regnander, J.R. 1989. The mites associated with Ips typographus in Sweden. Annales Entomologici Fennici, 55: 23-27.

Moser, J.C., Perry, T.J. and Furuta, K. 1997. Phoretic mites and their hyperphoretic fungi associated with flying Ips typographus japonicus Niijima (Col., Scolytidae) in Japan. Journal of Applied Entomology, 121: 425-428.

Moser, J.C. and Roton, L.M. 1971. Mites associated with southern pine bark beetles in Allen Parish, Louisiana. The Canadian Entomologist, 103: 1775-1798.

Økland, B., Flø D., Schroeder, M., Zach, P., Cocos, D., Martikainen, P., Siitonen, J., Mandelshtam, M.Y., Musolin, D.L., Neuvonen, S., Vakula, J., Nikolov, C., Lindelöw, Å. and Voolma, K. 2019. Range expansion of the small spruce bark beetle Ips amitinus: a newcomer in northern Europe. Agricultural and Forest Entomology, 21(3): 286-298.

Penttinen, R., Viiri, H. and Moser, J.C. 2013. The mites (Acari) associated with bark beetles in the Koli National Park in Finland. Acarologia, 53: 3-15.

Pernek, M., Hrasovec, B., Matosevic, D., Pilas, I., Kirisits, T. and Moser, J.C. 2008. Phoretic mites of three bark beetles (Pityocteines spp.) on Silver fir. Journal of Pest Science, 81: 35-42.

Pernek, M., Wirth, S., Blomquist S.R., Avtzis, D.N. and Moser, J.C. 2012. New associations of phoretic mites on Pityocteines curvidens (Coleoptera, Curculionidae, Scolytinae). Central European Journal of Biology, 7: 63-68.

Petrov, A.V. and Dostavalov, E.A. 2015. Change in aggressiveness of the bark beetles (Coleoptera: Curculionidae: Scolytinae) associated with pathogenic microorganisms. Izvestia Sankt-Peterburgskoj Lesotehniceskoj Akademii, 211: 76-91 (In Russian with English summary).

Raffa, K.F., Gregoire, J.-C. and Lindgren, B.S. 2015. Natural history and ecology of bark beetles. In: F.E. Vega and R. W. Hofstetter (Eds.). Bark Beetles, Biology and Ecology of Native and Invasive species. Chapter $1.1^{\text {st }}$ edition. Academic Press, Elsevier, pp. 1-28.

Scherbakov, A.N., Nikitsky, N.B., Polevoi, A.V. and Humala, A.E. 2013. On the beetle fauna of "Pasvik" Nature Reserve (Insecta, Coleoptera). Vestnik Mos- 


\section{A. A. Khaustov and I.A. Kerchev}

kovskogo Gosudarstvennogo Universiteta LesaLesnoi Vestnik, 6(98): 16-21. (In Russian, with English abstract).

Shcherbak, G.I. 1980. Kleshchi Semeystva Rhodacaridae Palearktiki [Mites of the Family Rhodacaridae of the Palaearctic]. Naukova Dumka, Kyiv. 215 pp. (In Russian)

Stark, V.N. 1952. Koroedy [Scolytid beetles]. In: A.A. Stackelberg (Ed.). Fauna SSSR [Fauna of the USSR]. New Series. Vol. 31: Coleoptera. No. 49. USSR Academy of Sciences, Moscow-Leningrad. 462 pp. (In Russian)

Stephen, F.M. and Kinn, D.N. 1980. Spatial distribution of mite associates of within-tree populations of Dendroctonus frontalis Zimm. Environmental Entomology, 9: 13-15.

Takov, D., Pilarska, D. and Moser, J. 2009. Phoretic mites associated with spruce bark beetle Ips typographus L. (Curculionidae: Scolytinae) from Bulgaria. Acta Zoologica Bulgarica, 61: 293-296.
Trach, V.A. and Khaustov, A.A. 2017. Mites of the genus Proctolaelaps Berlese, 1923 (Acari: Mesostigmata: Melicharidae) associated with bark beetles in Asian Russia. Acarina, 25(2): 151-163. DOI: 10.21684/0132-8077-2017-25-2-151-163

Voolma, K., Mandelshtam, M. Yu., Shcherbakov, A.N., Yakovlev, E.B., Õunap, H., Süda, I., Popovichev, B. G., Sharapa, T.V., Galasjeva, T.V., Khairetdinov, R.R., Lipatkin, V.A. and Mozolevskaya, E.G. 2004. Distribution and spread of bark beetles (Coleoptera: Scolytidae) around the Gulf of Finland: a comparative study with notes on rare species of Estonia, Finland and North-Western Russia. Entomologica Fennica, 15(4): 198-210.

Vrabec, M., Kaluz, S. and Ferenčik, J. 2012. Foretické roztoče na lykožrútovi smrekovom (Ips typographus) na vybraných lokalitách vo Vysokých Tatrách. Entomofauna Carpathica, 24: 1-14. 